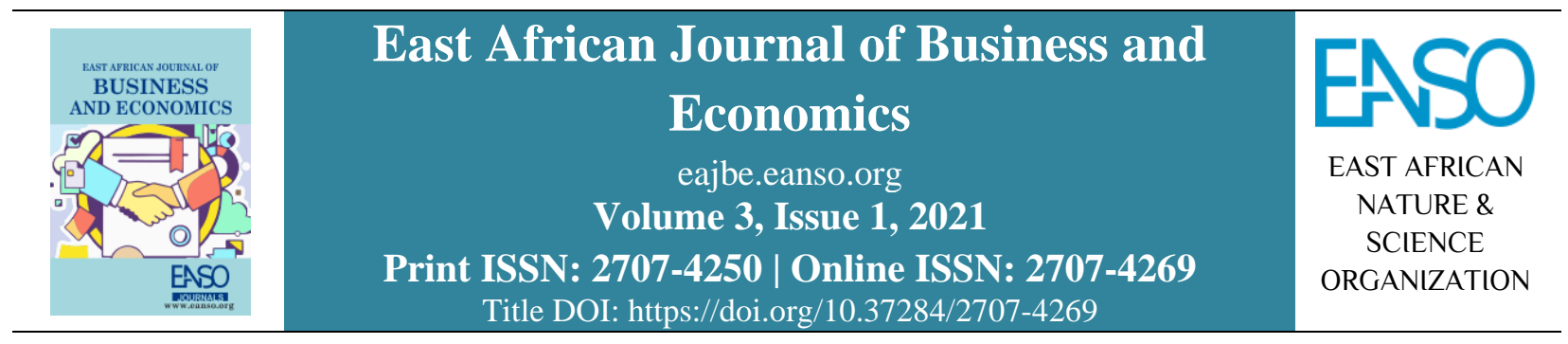

Original Article

\title{
Foreign Debts Strategy Thesis for Improved Living Standard: The Nigerian Experience
}

\author{
Ayangeadoo Alphonsus Hur-Yagba, PhD ${ }^{1^{*}}$, Helen Elena Jekele, PhD ${ }^{2}$ \& Kasim Umar, PhD \\ ${ }^{1}$ Faculty of Management Sciences, University of Abuja, P. M. B. 117, Gwagwalada - Abuja, Nigeria. \\ ${ }^{2}$ Faculty of Management Sciences, Baze University, Abuja, Nigeria. \\ * ORCID: https://orcid.org/0000-0001-5399-9880; Correspondence email: alphonsus.hur-yagba@ uniabuja.edu.ng.
}

Article DOI: https://doi.org/10.37284/eajbe.3.1.263

\section{Date Published: ABSTRACT}

07 January 2021 This study examined whether foreign debts have been able to improve or otherwise Nigeria's economy towards improving the living standard of her Keywords: citizenry with respect to the nation's gross domestic product (GDP), USD exchange rate, inflation rate and foreign direct investment (FDI) for the Foreign Debt, period 1986 to 2017. The study was carried out in Nigeria with respect to Strategy, other countries doing business with Nigeria. The study also made use of Gross Domestic Product, Exchange Rate, Inflation Rate,

Foreign Direct Investment. secondary data for the period under consideration. Data obtained were subjected to the cointegration test, which results show that the F-statistic is greater than the lower and upper bound critical value at a five per cent $(5 \%)$ significance level. Thus, the null hypothesis of no long-run relationship is rejected at a five per cent (5\%) significance level. It can, therefore, be inferred that the variables are cointegrated holding the external debt profile as the independent variable. Furthermore, the Ordinary Least Square Linear Multiple Regression Analyses (OLSLMRA) revealed that foreign debt significantly affected adversely, the nation's gross domestic product (GDP), USD exchange rate and foreign direct investment; except for inflation rate. The study, therefore, concluded that foreign debts, though not the best option for countries striving to survive; still have a significant effect on Nigeria's economy and indeed her living standard. The study recommends diversification of Nigeria's economy outside the crude oil to include agriculture, solid minerals, manufacturing, trade and industry to improve on her gross domestic product (GDP), exchange rate, inflation rate and foreign direct investment (FDI) and thus better the living standard of her citizenry.

\section{APA CITATION}

Hur-Yagba, A. A., Jekele, H. E., \& Umar, K. (2021). Foreign Debts Strategy Thesis for Improved Living Standard: The Nigerian Experience. East African Journal of Business and Economics, 3(1), 1-13. https://doi.org/10.37284/eajbe.3.1.263 
East African Journal of Business and Economics, Volume 3 Issue 1, 2021

Article DOI: https://doi.org/10.37284/eajbe.3.1.263

\section{CHICAGO CITATION}

Hur-Yagba, Ayangeadoo Alphonsus, Helen Elena Jekele, and Kasim Umar. 2021. "Foreign Debts Strategy Thesis for Improved Living Standard: The Nigerian Experience". East African Journal of Business and Economics 3 (1), 1-13. https://doi.org/10.37284/eajbe.3.1.263.

\section{HARVARD CITATION}

Hur-Yagba, A. A., Jekele, H. E. and Umar, K. (2021) "Foreign Debts Strategy Thesis for Improved Living Standard: The Nigerian Experience", East African Journal of Business and Economics, 3(1), pp. 1-13. doi: 10.37284/eajbe.3.1.263.

\section{IEEE CITATION}

A. A. Hur-Yagba, H. E. Jekele, and K. Umar, "Foreign Debts Strategy Thesis for Improved Living Standard: The Nigerian Experience", EAJBE, vol. 3, no. 1, pp. 1-13, Jan. 2021.

\section{MLA CITATION}

Hur-Yagba, Ayangeadoo Alphonsus, Helen Elena Jekele, and Kasim Umar. "Foreign Debts Strategy Thesis for Improved Living Standard: The Nigerian Experience”. East African Journal of Business and Economics, Vol. 3, no. 1, Jan. 2021, pp. 1-13, doi:10.37284/eajbe.3.1.263

\section{INTRODUCTION}

For developing nations, the normal route to better living standards according to their leaders is usually foreign debts which are normally readily available from such willing institutions such as the Paris Club and International Monetary Fund (IMF) among others. Leaders of such developing nations usually paint a hopeless picture of the inability of the workings of their economic systems such that the only viable outlet for any meaningful development remains through the foreign aid, grants and loans options. Provision of infrastructural facilities, employment, healthcare delivery, economic transformation among other reforms is usually the jingles developing nations' leaders use when embarking on foreign debts strategy campaigns for survival (Adepoju, Salau \& Obayelu, 2007). The presumption is that the debt will solve all problems and there will be a better standard of living.

Nigeria's first outing for foreign debt in 1958 was partly to develop her transportation infrastructure (the Railway construction) and other development projects (Ndekwe, 2008). This loan amounted to twenty-eight million US dollars (USD 28 million). The devastation caused by the Nigerian civil war between 1967 to 1970 paved the way for more foreign debts to cushion the adverse effects of the aftermath of the war. Since then, Nigeria's foreign debts regime took centre stage as she took another loan of 13.1 million US dollars from the Paris Club to construct the Niger Dam (Kainji Dam); and another "jumbo loan" of 1 billion US dollar from the International Capital Market (ICM) in 1978. With the continuous stockpiling of these debts, the interest rates and other charges were on the increase such that instead of these debts improving the nation's standard of living, the reverse was the case. Consequently, the outcome of the harsh payment conditions of these debts rather produced a slow economic development process that systematically aggravated Nigeria's infrastructural decay especially in education, social, health, transportation and other sectors of the economy. Hameed, Ashram and Chaudhary (20018) while referring to Pakistan notes that the consequences of higher foreign debts been characterised by low gross domestic product (GDP) and foreign direct investment (FDI) as well as higher USD exchange rate and inflation rate. It is in view of the foregoing that this study seeks to investigate if truly foreign debt prescription which was initially propagated as a panacea for economic recovery and improved standard of living for developing nations holds for every developing nation with Nigeria as a hypothetical case.

\section{REVIEW OF RELATED LITERATURE}

Ijeoma (2013) conducted an empirical analysis of the impact of debt on the Nigerian economy using some selected macroeconomic indicators in the Nigerian economy such as exchange rate, gross 
domestic product and gross fixed capital forum for thirty years (1980-2010). The study relied on the secondary data obtained from the country's Debt Management Office, Central Bank of Nigeria (CBN) Bulletin and internet materials. The regression analysis carried out revealed that (a) Nigeria's external debt stock has a significant impact on the nation's economic growth and (b) there is a positive relationship between the nation's debt payment and her gross fixed capital forum. On this basis, the study concluded that borrowed funds should strictly be channelled into the purpose for which it was borrowed. The study recommended that the country should borrow only when it becomes absolutory necessary.

Jilenga, Xu and Gondje-Dacka (2016) studied the Impact of External Debt and Foreign Direct Investment on Economic Growth: Empirical Evidence from Tanzania. The Time Series data was obtained from 1971 to 2011 . The empirical analysis employed the ARDL model and the Bounds test approach of cointegration as advocated by Pesaran et al. (2001) to test for long-run equilibrium relationships. The results revealed that it is possible for external debt to promote Tanzanian economic growth in the long-run, but the foreign direct investment will produce a negative impact on the country's economic growth. It was, however, clear from the results that, there was no evidence to suggest any form of casualty between external debt and economic growth or between foreign direct investment, inflation and economic growth in the short-run. The study concluded that Tanzania needs external debts to stimulate her economic growth. It was, therefore, recommended that the country can borrow to stimulate growth, but genuine efforts should be made to ensure proper management of these external debts as well as effective coordination of foreign direct investment.

Malik (2015) examined the impact of foreign direct investment on the economic growth of Pakistan. Findings showed that there was a positive relationship between gross domestic product and foreign direct investment (FDI). It was concluded that Pakistan should not hesitate in going into FDI to promote her economic growth. Melnyk, Kubatko \& Pysarenko (2014) investigated the impact of foreign investment on the growth of 26 postcommunist transition economies from 1988 to 2010. The results showed that FDI has an influence on the growth of these economies. Wamboye (2012) investigated the impact of public external debt on the long-term economic growth of forty least development countries (LCDs) using unbalanced panel data from 1975-2010. The results showed that high external debt reduces economic growth, irrespective of the debt. Furthermore, debt relief initiatives were shown to be very critical, as revealed in the lower negative debt effects on growth in HIPCs sub-sample relative to non-HIPCs sub-sample.

Sadib, Masnoon and Rafique (2013) investigated the impact of foreign direct investment on the host country's economy (Pakistan). Data was collected for the period 1981-2010. Apart from FDI, four other variables: debt, trade, inflation and domestic investment, were considered for the study and regressed on the country's GDP. Least Square method was adopted for analysis. The cointegration of the variables was obtained through the application of the Augmented Dickey-Fuller Test and was found to be true only in the long-run. The results showed that Pakistan's economic performance was negatively affected by foreign direct investment while her domestic investment enjoyed an economic boost. However, the nation's debt, trade and inflation were shown to have a negative impact on the country's GDP.

Romanus (2014) investigated external debt crisis, debt relief and economic growth in Nigeria in 2005. The argument was that huge external debt was responsible for Nigeria's slow economic growth and development. The study relied on secondary data and descriptive survey. Results revealed that lack of fiscal discipline, owing to lack of integrity and accountability; overdependence on oil revenue; 
poor project analysis and implementation were factors accounting for Nigeria's debt crises in the past. The study concluded that the debt relief enjoyed by Nigeria so far has not translated into the much-desired economic growth and development. It recommended strict adherence to policy guidelines to prevent debt over-hang.

\section{STATEMENT OF THE PROBLEM}

The issue at stake is that any time Nigeria was borrowing, the usual reason is always pinned down to economic development and improved standard of living, but realistically things seem to be getting rather worse in terms of the nations' gross domestic product (GDP) status, USD Exchange rate, inflation rate and foreign direct investment (FDI) among others. Meanwhile, it has always been noted that Nigeria's external debts had to increase over time because of a proportional shortage of foreign exchange to meet her development needs (AFRODAD, 2007). The various successive regimes usually maintain this position that the fall in the oil prices constantly affects government expenses such that for their regime to survive, they have to borrow to support the balance of payment and project financing. The situation became worse with the entrance of other tiers of governments into external loan obligation, decrease in the share of loans from bilateral and multinational creditors, the resultant increase borrowing from private sources at exorbitant rates and the inability to manage external debts prudently due to corruption and mismanagement of oil revenue (Van Wijnbergen, Rocha \& Anand, 2008; Abrego \& Ross, 2001). Apparently, the said history of Nigeria's huge debts can hardly be separated from its decades of misrule and the continuous recklessness of her rulers (Soludo, 2003; Ikeje, 2009). This study seeks to investigate why continuous external borrowing by various Nigerian regimes (leaders) could not guarantee such development needs and improve the living standard of Nigerian citizens with respect to gross domestic product (GDP) status, USD Exchange rate, inflation rate and foreign direct investment (FDI). To investigate the extent of the impacts of Nigeria's foreign debts, the following hypotheses were made:

$H_{0 I}$ : Foreign Debts do not significantly improve the Gross Domestic Product GDP status in Nigeria.

$H_{02}$ : Foreign Debts do not significantly affect the USD Exchange rate in Nigeria.

$H_{03}:$ Foreign Debts do not significantly influence the inflation rate in Nigeria.

H04: Foreign Debts do not Significantly influence Foreign Direct Investment (FDI) in Nigeria.

\section{METHODOLOGY AND MODEL SPECIFICATION}

Having looked at the theoretical framework underpinnings of the monetary model of macroeconomic variables (GDP, US\$ Exrate, inflation rate, FDI) determination, the task in this section was to construct a model relating the various variables identified as key factors within the context of the external debt model in Nigeria. For this purpose, the model adopted for this study is predicated on the monetary model of economic performance determination variables of Frankel (1976) and Bilson (1978) and a modified model of Rapach and Wohar (2002). The preferred model is represented as equation 1,2, 3 and 4 below:

$$
\begin{aligned}
& G D P=\beta_{o}+\operatorname{Debt} \beta_{1}+\mu \ldots \ldots \ldots \ldots \ldots . .1 \\
& \text { EXTrate }=\beta_{o}+\operatorname{Debt} \beta_{1}+\mu \ldots \ldots \ldots \ldots . .2 \\
& \text { INFrate }=\beta_{o}+\operatorname{Debt} \beta_{1}+\mu \\
& F D I=\beta_{o}+\operatorname{Debt} \beta_{1}+\mu \ldots \ldots \ldots \ldots \ldots \ldots . .4
\end{aligned}
$$

Where: $\mathrm{DEBT}=$ Nigeria's foreign debt; $\mathrm{EXR}=$ official exchange rate; GDP = gross domestic product growth rate as a measure of income; FDI = foreign direct investment; INFR = inflation rate as 
a measure of price stability; ${ }^{\mu}=$ other variables not explicitly included in the model.

\section{Estimation Technique and Procedure}

In order to investigate the relationship that exists between the dependent variable and explanatory variables, this study adopted the following procedures. First, the study took the first pass at the data in the form of descriptive statistics and correlation matrix of all the variables in order to determine their inter-relationships. Thus, simple averages of descriptive statistics and correlation matrix were employed to analyse the various trends in the data. Next, the study examined the timeseries properties of the variables. Thus, the variables were investigated for their stochastic properties, using two traditional and one modern unit roots tests. The traditional tests deployed are the Augmented Dickey-Fuller (ADF) and PhillipsPerron (PP). However, traditional tests for unitroots (e.g. ADF and PP) have low power in the presence of structural breaks and have a tendency to "detect" non-stationarity which does not exist in the data. To avoid invalid inferences, the study employed a unit root test with a structural break by Perron (2006) to determine the breakpoints/dates as well as further investigate the properties of the time series employed.

The unit root tests are followed by the test of cointegration using the Autoregressive Distributed Lag (ARDL) bounds testing approach to cointegration proposed by Pesaran et al. (2001). This technique has a number of advantages over Johansen cointegration techniques. First, whereas the Johansen techniques require large data samples, a luxury that most developing economies do not have, the ARDL model is the most useful method of determining the existence of cointegration in small samples (Ghatak \& Siddiki, 2001).

The second advantage of ARDL approach is that while other cointegration techniques require all of the regressors to be of the same order, the ARDL approach can be applied whether the variables in the regression are purely of I(I) and/or purely I(0) or a mixture of both. This implies that the ARDL approach avoids the pre-testing problem associated with standard cointegration, which requires that the variables be already classified into I(I) (Pesaran et al., 2001). Thirdly, the ARDL approach to cointegration is superior to the Johansen approach because it avoids the problem of too many choices that are to be made in the Johansen method. These include the treatment of deterministic elements, the order of VAR and the optimal lag length to be used. Finally, in the ARDL approach variables could have different lag lengths, whereas in the Johansen method this is not permissible.

The ARDL approach requires two steps. In the first step, the existence of any long-run relationship among the variables of interest is determined by using the F-test or bound testing approach. The second stage requires the estimation of the long-run relationship between dependent and explanatory variables and to determine their values, thereafter the short-run elasticity of the variables with the error correction representation of the ARDL model. The purpose of applying the ECM version of the ARDL is to determine the speed of adjustment to equilibrium. Here the study is interested only in establishing long-run relationships. Therefore, the short-run part of the ARDL will not be considered.

The lag length or order of the variables was selected by using Akaike Information Criteria (SIC). The AIC is often preferred as it gives the heaviest penalties for loss of a degree of freedom (Ogwumike \& Ikenna, 2012). AIC also imposes a larger penalty for additional coefficients. To test for the cointegration relationship using the ARDL approach based on the F-statistic or Wald statistic, the study states null hypotheses of no cointegration against the alternative hypothesis of cointegration among the variables in the model as follows:

$\mathrm{H}_{0}: \alpha_{5}=\alpha_{6}=\alpha_{7}=\alpha_{8}=\alpha_{9}=0$ 
East African Journal of Business and Economics, Volume 3 Issue 1, 2021

Article DOI: https://doi.org/10.37284/eajbe.3.1.263

$\mathrm{H}_{1:} \alpha_{5}=\alpha_{6}=\alpha_{7}=\alpha_{8}=\alpha_{9} \neq 0$

The acceptance or rejection of the hypothesis is based on a comparison between the calculated Fstatistic and the F-statistic tabulated by Pesaran et al. (2001) and for small samples by Narayan (2005). The tabulated F-statistic has both upper and lower bounds critical values and if the calculated Fstatistic is higher than the upper bounds, the null hypothesis is rejected and the alternative hypothesis is accepted that there is a cointegration relationship between the variables. But if the calculated Fstatistic is lower than the lower bound critical value, the null hypothesis is accepted and the alternative hypothesis is rejected, meaning that there is no cointegration relationship between the variables. However, further analysis with the ordinary least square regression analysis. The Regression Analysis will be conducted to determine the extent and direction of the effect of Nigeria's Foreign Debts and some selected economic variables. It will also measure the homogeneity of the impact across

Table 1: Summary of Statistics Results the industrial sectors of the country, as stated in the above model specification.

\section{Nature and Sources of Data}

The study depends on secondary data that were obtained from the Central Bank of Nigeria (CBN) Statistical Bulletin issues, National Bureau of Statistics and World Development Indicators for Nigeria (WDI). It covers the period from 1986 to 2017.

\section{RESULTS AND DISCUSSION}

In order to have a glimpse of the data used in the study, a first pass at the data in the form of descriptive statistics was carried out. The empirical section begins by analysing the summary statistics of all the variables in order to determine their interrelationships. This gives us a good idea of the patterns in the data and the nature of the estimations and diagnostics to be carried out. The summary statistics are presented below.

\begin{tabular}{llllll}
\hline & DEBT & EXR & GDP & FDI & INFR \\
\hline Skewness & 0.034742 & 1.455885 & 1.713762 & 0.907165 & 1.574261 \\
Kurtosis & 2.360635 & 5.479119 & 10.31255 & 4.450254 & 4.249297 \\
Jarque-Bera & 0.534254 & 18.88989 & 84.24417 & 6.968578 & 14.82050 \\
Probability & 0.765576 & 0.000079 & 0.000000 & 0.030676 & 0.000605 \\
Observations & 31 & 31 & 31 & 31 & 31 \\
\hline
\end{tabular}

Table 1 shows the summary of descriptive statistics of the variables included in the model. It shows the existence of wide variations in the variables as depicted by the mean values during the 1986 to 2017 study period. All the distributions are positively skewed. Variables with the value of kurtosis less than three are called platykurtic (fat or short-tailed) and DEBT variable qualified for this during the study period. On the other hand, variables whose kurtosis value is greater than three are called leptokurtic (slim or long-tailed) and EXR, GDP, FDI and INFR variables qualified for this during the study period. Jarque-Bera test shows that the residuals are all not normally distributed but with the exception of the DEBT variable since the probability values exceed 5\%. In summary, the descriptive statistics revealed that the majority of the data sets are not normally distributed. This is so because the probability values of the variables do not exceed $5 \%$.

\section{Time Series Properties of the Variables}

Econometric studies have shown that most financial and macro-economic time series variables are nonstationary and using non-stationary variables leads to spurious regression (Engel \& Granger, 1987). 
East African Journal of Business and Economics, Volume 3 Issue 1, 2021

Article DOI: https://doi.org/10.37284/eajbe.3.1.263

Thus, the variables were investigated for their stochastic properties, using two traditional unit roots tests. The traditional tests deployed are the Augmented Dickey-Fuller (ADF) and PhillipsPerron (PP). The two tests were used to test for consistency and where conflicts exist, to decide on the most appropriate option (see Hamilton, 1994). The results of unit root tests are presented in Table 2 below:

Table 2: Traditional Unit Root Test Results (Trend and Intercept)

\begin{tabular}{llllllll}
\hline Variables & ADF & $\begin{array}{l}\text { Critical } \\
\text { Values }\end{array}$ & $\begin{array}{l}\text { Order } \\
\text { Integration }\end{array}$ & of & PP & $\begin{array}{l}\text { Critical } \\
\text { Values }\end{array}$ & $\begin{array}{l}\text { Order } \\
\text { Integration }\end{array}$ \\
\hline DEBT & -3.386 & $-3.222 * * *$ & $\mathrm{I}(1)$ & -3.365 & $-3.222^{*} * *$ & $\mathrm{I}(1)$ \\
EXR & -3.525 & $-3.222 * * *$ & $\mathrm{I}(0)$ & -8.775 & $-4.309 *$ & $\mathrm{I}(1)$ \\
GDP & -4.283 & $-3.568 * *$ & $\mathrm{I}(0)$ & -4.226 & $-3.568 * *$ & $\mathrm{I}(0)$ \\
FDI & -5.817 & $-4.374 *$ & $\mathrm{I}(0)$ & -5.729 & $-4.297 *$ & $\mathrm{I}(0)$ \\
INFR & -6.249 & $-4.441 *$ & $\mathrm{I}(1)$ & -6.128 & $-4.309 *$ & $\mathrm{I}(1)$ & \\
\hline
\end{tabular}

Note: * Indicates stationary at the $1 \%$ level.

From Table 2, the traditional test of the ADF indicates that all the variables tend to be stationary at level except DEBT and INFR which tends to be stationary at first difference. Similarly, the traditional test of the PP indicates that GDP and FDI variables tend to be stationary at level except for DEBT, EXT and INFR which tends to be stationary at first difference. However, these traditional tests for unit-roots (ADF and PP) have low power in the presence of structural breaks and have a tendency to "detect" non-stationarity which does not exist in the data. Not allowing for multiple structural breaks can cause acceptance of the unit root null hypothesis by tests that incorporate only one break (Ben-David, Lumsdaine \& Papell, 2003). It is also crucial to have knowledge of breakpoint because accurately evaluating any programme intended to engender structural changes in the economy depends on it (Piehl, Cooper, Braga \& Kennedy, 1999). To avoid invalid inferences, the study employed a unit root test with a structural break by Perron (2006) to determine the breakpoints/dates as well as further investigate the properties of the time series employed.

\section{Co-integration Test}

The Autoregressive Distributed Lag (ARDL) bounds testing approach is used to re-examine the validity of the monetary exchange rate model in Nigeria nominal exchange rates naira to America dollar for the period 1986 to 2017 covering the era of floating exchange rate regime. The different order of integration of the variables necessitates the choice of the ARDL- Bounds testing approach to cointegration which is suitable for testing long-run relationships among variables that are of mixed order of integration. The result of the cointegration test is presented in Table 3 below: 
East African Journal of Business and Economics, Volume 3 Issue 1, 2021

Article DOI: https://doi.org/10.37284/eajbe.3.1.263

Table 3: Result of ARDL Bounds Test for Cointegration

\begin{tabular}{lll}
\hline \multicolumn{2}{l}{ Null Hypothesis: No Long-run Relationships Exist } & \\
\hline Test Statistic & Value & $\mathrm{K}$ \\
F-Statistic & 4.588860 & 4 \\
Critical Value Bounds & & \\
Significance & Lower Bound & Upper Bound \\
$5 \%$ & 2.86 & 4.01 \\
\hline
\end{tabular}

Source: Researcher's Computations Using E-views 9.5

The cointegration test result shows that the Fstatistic is greater than the lower and upper bound critical value at the $5 \%$ significance level. Thus, the null hypothesis of no long-run relationship is rejected at the 5\% significance level. It can, therefore, be inferred that the variables are cointegrated holding the external debt profile as the independent variable.

The finding that the variables are cointegrated indicates that the monetary model would have longrun validity. This result contrasts sharply with the findings of Nieh and Wang (2005) that were unable to discover even a long-run relationship for the monetary variables, using Johansen's maximum likelihood cointegration test and the ARDL Bound test. They found ambiguous results for the long-run equilibrium relationship between the External Debt profile and macro fundamentals. With the aid of ARDL Bound test, they conclude that there is no long-run equilibrium relationship between exchange rates and macro fundamentals. However, the result is consistent with earlier studies by Frenkel (1976), Bilson (1978), Macdonald and Taylor (1991), Rapach and Wohar (2002) and Jimoh (2004), Nwafor (2006) for Nigeria to mention a few. The regression analysis is, therefore, conducted to further give an insight into the direction of impact on the Macroeconomic variables by the external debt with the postulation of four relevant research hypotheses.

\section{Hypotheses Testing}

Four (4) research hypotheses were formulated and tested with the use of inferential statistics. The hypothesis was tested with ordinary linear regression analysis at 0.05 level of significance.

Hypothesis 1: Foreign Debts do not significantly improve Nigeria's Gross Domestic Product GDP to the extent of enhancing the living standard of her citizenry.

Table 4a: Model Summary

\begin{tabular}{|l|l|l|l|l|}
\hline Model & $\mathbf{R}$ & R Square & Adjusted R Square & Std. Error of the Estimate \\
\hline 1 & $.497^{\mathrm{a}}$ & .247 & .231 & $1.71688 \mathrm{E} 5$ \\
\hline \multicolumn{4}{|l}{. Predictors: (Constant), Debt } \\
\hline
\end{tabular}

Table 5: Regression Output for the relationship between Nigeria's foreign debt profile and the country's Gross Domestic Product GDP

\begin{tabular}{|c|c|c|c|c|c|c|}
\hline \multirow{2}{*}{\multicolumn{2}{|c|}{ Model }} & \multicolumn{2}{|c|}{ Unstandardised Coefficients } & \multirow{2}{*}{$\begin{array}{l}\text { Standardised Coefficients } \\
\text { Beta }\end{array}$} & \multirow[b]{2}{*}{$t$} & \multirow[b]{2}{*}{ Sig. } \\
\hline & & B & Std. Error & & & \\
\hline 1 & (Constant) & 135202.285 & 27574.062 & & 4.903 & 0 \\
\hline & Debt & 0.078 & 0.02 & 0.497 & 3.966 & 0.001 \\
\hline
\end{tabular}


The regression analysis results in Table 5 indicate that "Foreign Debt" which yielded a Beta $(\beta)$ value of 0.078 , t-value of 3.966, and a p-value of 0.001 , was significant since the $\mathrm{p}$-value is less than 0.05 level of significance. This implies that a unit change in the level of the Foreign Debt (a unit increase or decrease) will significantly have a corresponding effect on Nigeria's gross domestic product (GDP) by a factor of 0.078 . Also, from Table $4, \mathrm{R}^{2}$ of 0.497 indicates that up to $49.7 \%$ of the extent of the variability in the gross domestic product (GDP) of Nigeria is accounted for by the independent variables "external debt". It follows that other extraneous variables such as excessive government spending, excessive consumption pattern that is import driven and lack of manufacturing companies that would have created more jobs for the citizens thereby enhancing their living standards could have been responsible for the remaining $50.3 \%$ variability in GDP,

Table 6: Model Summary

\begin{tabular}{|l|l|l|l|l|}
\hline Model & R & R Square & Adjusted R Square & Std. Error of the Estimate \\
\hline 1 & $.697^{\mathrm{a}}$ & .485 & .475 & 37.66172 \\
\hline
\end{tabular}

Table 7: Regression Output for the relationship between Nigeria's Foreign Debt Profile and the U.S. Exchange rate

\begin{tabular}{|c|c|c|c|c|c|c|}
\hline \multirow{2}{*}{\multicolumn{2}{|c|}{ Model }} & \multicolumn{2}{|c|}{ Unstandardised Coefficients } & Standardised Coefficients & \multirow[t]{2}{*}{$t$} & \multirow[t]{2}{*}{ Sig. } \\
\hline & & B & Std. Error & Beta & & \\
\hline \multirow[t]{2}{*}{1} & (Constant) & 16.605 & 6.049 & & 2.745 & .008 \\
\hline & Debt & $2.914 \mathrm{E}-5$ & .000 & .697 & 6.728 & .001 \\
\hline
\end{tabular}

The regression analysis results in Table 7 indicate that "Foreign Debt" which yielded a Beta $(\beta)$ value of $2.914 \mathrm{E}-5$, at-value of 6.728 , and a p-value of 0.001 , was significant since the $\mathrm{p}$-value is less than 0.05 level of significance. This implies that a unit change in the level of the Foreign Debt (a unit increase or decrease) will significantly have a corresponding effect on the USD Exchange rate by a factor of 2.914E-5. Also, from Table $6, \mathrm{R}^{2}$ of
Hypothesis 1 was therefore rejected and we conclude that Foreign Debts do not significantly improve Nigeria's Gross Domestic Product (GDP) to the extent in enhancing the living standard of her citizens. Hypothesis 1 which states that "Foreign Debts do not significantly improve Nigeria's Gross Domestic Product GDP to the extent of enhancing the living standard of her citizenry" was therefore rejected and we conclude that though, foreign debts have the potential of improving the country's GDP as the Nigerian government is always reporting, such improved GDP is not capable of enhancing the nation's standard of living in the face of massive overpricing of invoices, excessive spending, high import dependent rate among others.

Hypothesis 2: Foreign Debts do not significantly affect Nigeria's USD Exchange rate positively to the extent of improving citizens' standard of living.
0.697 indicates that up to $69.7 \%$ of the extent of the variability in the USD Exchange rate of Nigeria is accounted for by the independent variables "External Debt". This suggests that other extraneous variables such as interest rates, inflation rates, trade balance, low degree of transparency in the conduct of leaders and administrators among others could have been responsible for the remaining $30.3 \%$ variability in the exchange rate, 
Hypothesis 2 which states that "Foreign Debts does not significantly affect Nigeria's USD Exchange rate positively to the extent of improving citizens' standard of living" was, therefore, rejected and we conclude that, Foreign Debts do not significantly affect the USD Exchange rate positively to the degree of ensuring Nigeria's standard of living.

Hypothesis 3: Foreign Debts do not significantly influence Nigeria's inflation rate positively to improve her standard of living.

Table 8: Model Summary

\begin{tabular}{|l|l|l|l|l|}
\hline Model & R & R Square & Adjusted R Square & Std. Error of the Estimate \\
\hline 1 & $.020^{\mathrm{a}}$ & .000 & -.020 & 18.49480 \\
\hline
\end{tabular}

Table 9: Regression Output for the relationship between Nigeria's Foreign Debt Profile and the Inflation Rate.

\begin{tabular}{|l|l|l|l|l|l|l|}
\hline \multirow{2}{*}{ Model } & Unstandardised Coefficients & Standardised Coefficients & \multirow{2}{*}{ S } & \multirow{2}{*}{ Sig. } \\
\cline { 3 - 7 } \multicolumn{2}{|l|}{1} & B & Std. Error & Beta & & \\
\cline { 2 - 4 } & Debt & 17.174 & 2.970 & & 5.782 & .000 \\
\hline \multicolumn{2}{|l}{ a. Dependent Variable: Inflation Rate } & .000 & .020 & .139 & .890 \\
\hline
\end{tabular}

The regression analysis results in Table 9 indicate that "Foreign Debt" which yielded a Beta $(\beta)$ value of 2.967E-7, at-value of 0.139 , and a p-value of 0.890 , was not-significant since the p-value is not less than 0.05 level of significance. This implies that a unit change in the level of the Foreign Debt (a unit increase or decrease) will not significantly have a corresponding effect on the Inflation rate by a factor of 2.967E-7. Also, from Table 8, $\mathrm{R}^{2}$ of 0.020 indicates that up to $2 \%$ of the extent of the variability in the inflation rate in Nigeria is accounted for by the independent variables "External Debt". This means that other extraneous variables including the excessive supply of money in the economy by the politicians, high exchange rate and high national debts could have been responsible for the remaining $98 \%$ variability in the Inflation rate. Thus, we do not have sufficient reason to reject Hypothesis 3, which states that "Foreign Debts do not significantly influence Nigeria's inflation rate positively to improve her standard of living". Therefore, we conclude that Foreign Debts do not significantly influence Nigeria's inflation rate to the extent of improving her standard of living.

Hypothesis 4: Foreign Debts do not Significantly influence Foreign Direct Investment (FDI) in Nigeria sufficiently to improve her standard of living.

Table 10: Model Summary

\begin{tabular}{|l|l|l|l|l|}
\hline Model & $\mathbf{R}$ & R Square & Adjusted R Square & Std. Error of the Estimate \\
\hline 1 & $.367^{\mathrm{a}}$ & .135 & .117 & $1.76071 \mathrm{E} 5$ \\
\hline
\end{tabular}


East African Journal of Business and Economics, Volume 3 Issue 1, 2021

Article DOI: https://doi.org/10.37284/eajbe.3.1.263

Table 11: Regression Output for the relationship between Nigeria's Foreign Debt Profile and FDI

\begin{tabular}{|l|l|l|l|l|l|l|}
\hline \multicolumn{2}{|l}{ Model } & Unstandardised Coefficients & Standardised Coefficients & \multirow{2}{*}{ Sig. } \\
\cline { 3 - 7 } \multicolumn{2}{|l|}{1} & B & Std. Error & Beta & & \\
\cline { 2 - 4 } & Debt & 99638.277 & 28278.074 & & 3.524 & .001 \\
\hline \multicolumn{2}{|l|}{ a. Dependent Variable: FDI } & .055 & .367 & 2.735 & .009 \\
\hline
\end{tabular}

The regression analysis results in Table 11 indicate that "Foreign Debt" which yielded a Beta $(\beta)$ value of 0.055 , at-value of 2.735 , and a p-value of 0.009 , was significant since the p-value is less than 0.05 level of significance. This implies that a unit change in the level of the Foreign Debt (a unit increase or decrease) will significantly have a corresponding effect on the FDI by a factor of 0.055 . Also, from Table $10, \mathrm{R}^{2}$ of 0.367 indicates that up to $36.7 \%$ of the extent of the variability in the FDI of Nigeria is accounted for by the independent variables "External Debt". This means that the remaining $63.3 \%$ extraneous variables could be responsible

Table 12: Hypotheses Decision Summary for the variability in the FDI of the nation's inability to guarantee long-term relationships reflecting lasting interest and control by either the foreign investor or resident Nigerian enterprise in the economy. Thus, we reject the hypothesis 4 , which states that "foreign debts do not significantly influence foreign direct investment (FDI) in Nigeria sufficiently to improve her standard of living" and therefore, we conclude that Foreign Debts do not Significantly influence Foreign Direct Investment (FDI) in Nigeria to the level of sufficiently improving her living standard.

\begin{tabular}{llll}
\hline Hypotheses & Variables & Level of sig (0.05) & Decision \\
\hline 1 & Debt/GDP & 0.001 & Reject \\
2 & Debt/USD Exchange Rate & 0.001 & Reject \\
3 & Debt/Inflation Rate & 0.890 & Accept \\
4 & Debt/FDI & 0.009 & Reject \\
\hline
\end{tabular}

\section{CONCLUSION AND RECOMMENDATION}

From the foregoing, we can conclude that, although Foreign Debts significantly influenced the Gross Domestic Product (GPD), USD Exchange Rate and Foreign Direct Investment in Nigeria, such influence was not enough to significantly guarantee the improved living standard of her citizens except Inflation Rate. This may be attributed to the nation's overdependence on crude oil whose prices can hardly be predictable, rising cost of debts servicing, mismanagement among others. These have contributed to the poor standard of living of the nation's citizens significantly.
The study recommends strict economic discipline as well as diversification of Nigeria's economy outside the crude oil to include agriculture, solid minerals, manufacturing, trade and industry to improve on her Gross Domestic Product (GDP), Exchange Rate Inflation Rate and Foreign Direct Investment (FDI) for better-improved living standard. 


\section{REFERENCES}

Abrego, R. N. \& Ross, D. C. (2001). Debt Relief under Heavily Indebted Poor Countries (HIPS) Initiative: Create an Outlook for Debt Sustainability and Resource Flow. Wider Discussion Paper September. United Nations University.

Adepoju, A. A., Salau, A. S., \& Obayelu, A. E. (2007). The effects of external debt management on sustainable economic growth and development: lessons from Nigeria. MPRA Paper No. 2147. Munich Personal RePEc Archive.

AFODAD. (2007). Nigeria: foreign debts, stolen wealth, IFIS and the west: a case study. Harare: African Forum and Network on Debt and Development.

Ben-David, D., Lumsdaine, R. L., \& Papell, D. H. (2003). Unit roots, postwar slowdowns, and long-run growth: evidence from two structural breaks. Empirical Economics, 28(2), 303-319.

Bilson, J. F. O. (1978). Rational expectations and the exchange rate. In Frankel, J. A. \& Johnson, H. G. (Eds), The Economics of Exchange Rates (75-96). Adison-Wesley Press.

Engle, R. and Granger, C. (1987) Cointegration and Error Correction: Representation, Estimation and Testing. Econometrica, 55, 251-276. http://dx.doi.org/10.2307/1913236

Frenkel, J. A. (1976). A monetary approach to the exchange rate: doctrinal aspects and empirical evidence. The Scandinavian Journal of Economics, 200-224.

Ghatak, S., \& Siddiki, J. U. (2001). The use of the ARDL approach in estimating virtual exchange rates in India. Journal of Applied Statistics, 28(5), 573-583.
Hameed, A., Ashraf, H., \& Chaudhary, M. A. (2008). External debt and its impact on economic and business growth in Pakistan. International Research Journal of Finance and Economics, 20(1), 132-140.

Hamilton, J. D. (1994). “Time Series Analysis (Princeton University Press, Princeton, NJ) ISBN 0-691-04289-6" International Journal of Forecasting, Elsevier, 11(3),494

Ijeoma, N. B. (2013). An empirical analysis of the impact of debt on the Nigerian economy. AFRREV IJAH: An International Journal of Arts and Humanities, 2(3), 165-191.

Ikeje, I. (2009). While Nigeria must be Conscious of about Incurring More External Debts. Business Day, 8(115).

Jilenga, M. T., Xu, H., \& Gondje-Dacka, I. M. (2016). The impact of external debt and foreign direct investment on economic growth, empirical evidence from Tanzania. International Journal of Financial Research, 7 (2), 154-162.

Jimoh, A. (2004). The monetary approach to exchange rate determination: Evidence from Nigeria. Journal of Economic Cooperation, 25(2), 109-130.

MacDonald, R., \& Taylor, M. P. (1991). The monetary approach to the exchange rate: longrun relationships and coefficient restrictions. Economics Letters, 37(2), 179-185.

Malik, K. (2015). Impact of foreign direct investment on economic growth of Pakistan. American Journal of Business and Management, 4(4), 190-202.

Melnyk, L., Kubatko, O., \& Pysarenko, S. (2014). The impact of foreign direct investment on economic growth: case of post-communist transition economies. Problems and perspectives in management, 12(1), 17-24. 
Ndekwe, E. C. (2008). Government Borrowing, Monetary Supply and Monetary Policy in Nigeria: Government's Monetary Impact in Mixed Economy. Ibadan: Nigeria Institute of Social and Economic Research.

Nieh, C. C., \& Wang, Y. S. (2005). ARDL approach to the exchange rate overshooting in Taiwan. Review of Quantitative Finance and Accounting, 25(1), 55-71.

Nwafor, F. C. (2006). The naira-dollar exchange rate determination: a monetary perspective. International Research Journal of Finance and Economics, 5, 130-135.

Ogwumike, F. O., \& Ikenna, O. D. (2012). Financial liberalisation and domestic savings in Nigeria. Journal of Social sciences, 7(4), 635646.

Perron, P. (2006). Dealing with Structural Breaks. Palgrave Handbook of Econometrics, 1, 278352.

Piehl, A. M., Cooper, S. J., Braga, A. A., \& Kennedy, D. M. (1999). Testing for structural breaks in the evaluation of programs (No. w7226). National Bureau of Economic Research.

Rapach, D. E., \& Wohar, M. E. (2002). Testing the monetary model of exchange rate determination: new evidence from a century of data. Journal of International Economics, 58(2), 359-385.

Romanus, O. O. (2014). External debt crisis, debt relief and economic growth: Lessons from Nigeria. European Journal of Business and Management, 6(33), 85-88.

Saqib, N., Masnoon, M., \& Rafique, N. (2013). Impact of foreign direct investment on economic growth of Pakistan. Advances in Management \& Applied Economics, 3(1), 3545.
Soludo, C. C. (2001). Debt, poverty, and inequality: towards an exit strategy for Nigeria and Africa. International Conference on Sustainable Debt Strategy. NICON, Abuja, 17-18.

Van Wijnbergen, S., Rocha, R., \& Anand, R. (1989). Inflation, external debt, and financial sector reform: a quantitative approach to consistent fiscal policy. Policy Research Working Paper Series 261. The World Bank.

Wamboye, E. (2012). External Debt, Trade and FDI on Economic Growth of Least Developed Countries. MPRA Paper No. 39031. Munich Personal RePEc Archive. 